\title{
Betaine Increases the Butyrylcholinesterase Activity in Rat Plasma
}

\author{
K. ŠIŠKOVÁ ${ }^{1,2}$, M. DUBNIČKOVÁ ${ }^{2}$, L. PAŠKOVÁ ${ }^{2}$, D. RAJDL ${ }^{1}$, Z. ĎURAČKOVÁ ${ }^{3}$, \\ J. MUCHOVÁ ${ }^{3}$, I. PAULIKOVÁ ${ }^{2}$, J. RACEK ${ }^{1}$
}

${ }^{1}$ Institute of Clinical Biochemistry and Hematology, Faculty of Medicine, Charles University and Faculty Hospital, Pilsen, Czech Republic, ${ }^{2}$ Department of Cell and Molecular Biology of Drugs, Faculty of Pharmacy, Comenius University, Bratislava, Slovak Republic, ${ }^{3}$ Institute of Medical Chemistry, Biochemistry and Clinical Biochemistry, Faculty of Medicine, Comenius University, Bratislava, Slovak Republic

Received March 6, 2015

Accepted August 28, 2015

On-line November 24, 2015

\section{Summary}

The physiological function of butyrylcholinesterase (EC 3.1.1.8, $\mathrm{BChE}$ ) is not clearly understood, but a role was suggested in the fat utilization process, resulting in positive correlation between plasma triglyceride (TG) levels and BChE activity. Consequently we tested the hypothesis that regular intake of betaine, a natural compound intervening in the liver TG metabolism could influence the BChE activity. The BChE activity was estimated spectrophotometrically in plasma of rats fed with betaine enriched standard (B) or high-fat diet (HFB). The results confirmed decreased TG plasma levels after betaine treatment independently on the type of diet $(0.15 \pm 0.03$ (B) vs. $0.27 \pm 0.08$ (control) $\mathrm{mmol} / \mathrm{l} ; \mathrm{p}=0.003$ and $0.13 \pm 0.03$ (HFB) vs. $0.27 \pm 0.08$ (control) $\mathrm{mmol} / \mathrm{l} ; \mathrm{p}=0.005$ ). The $\mathrm{BChE}$ activity increased significantly with betaine administration, however the change was more distinct in the HFB group $(0.84 \pm 0.34$ (HFB) vs. $0.22 \pm 0.04$ (control) O.D./min/mg; $\mathrm{p}<0.001$ and $0.41 \pm 0.11$ (B) vs. $0.22 \pm 0.04$ (control) O.D./min/mg; $\mathrm{p}=0.001$ ). In conclusion, betaine intake led to elevated BChE activity in plasma and this effect was potentiated by the HF diet. Since betaine is in general used as a supplement in the treatment of liver diseases accompanied by TG overload, its impact on the BChE activity in the role of the liver function marker should be taken into account.

\section{Key words}

Butyrylcholinesterase • Betaine • High-fat diet • Liver • Lipid metabolism

\section{Corresponding author}

K. Šišková, Institute of Clinical Biochemistry and Hematology, Faculty of Medicine, Charles University and Faculty Hospital, Alej Svobody 80, 30460 Pilsen, Czech Republic. E-mail: katarina.siskova@gmail.com

\section{Introduction}

Unlike the vital function of acetylcholinesterase (EC 3.1.1.7) in the process of acetylcholine breakdown, the accurate physiological role of the other enzyme of the cholinergic system - butyrylcholinesterase (EC 3.1.1.8, $\mathrm{BChE}$ ) remains the research target for many scientists. The task would be easier, if the specific biological substrate for BChE was known. Therefore, $\mathrm{BChE}$ has been so far studied mainly in the context of different pathological conditions, where its activity appeared to have at least some relevance. This covers predominantly the field of neurological disorders (especially Alzheimer's disease), intoxications with organophosphates and metabolic disorders (Cokugras 2003). Vigorous interest in the research of the relationship between $\mathrm{BChE}$ and the lipid metabolism was launched by observing that the $\mathrm{BChE}$ activity correlated positively with levels of triglycerides (TG) in plasma (Annapurna et al. 1991). The following studies concluded that BChE activity correlated also with other markers of the lipid metabolism (total cholesterol (TC), LDL-chlesterol, visceral fat area, subcutaneous fat area, body mass index) or even insulin resistance (Rustemeijer et al. 2001, 
Alcantara et al. 2002, Iwasaki et al. 2007). The fact that the selective $\mathrm{BChE}$ inhibitor iso-OMPA (tetraisopropyl pyrophosphoramide) decreased TG levels in plasma of rats pointed out to a possible direct participation of $\mathrm{BChE}$ in TG metabolism (Annapurna et al. 1991). Also, the BChE knockout mouse had elevated TG plasma levels and became obese on high-fat diet, in contrast to the wild-type littermates ( $\mathrm{Li}$ et al. 2008). This compelling evidence could predicate of $\mathrm{BChE}$ necessity for an appropriate lipolysis.

Involvement of $\mathrm{BChE}$ in the lipid metabolism is supported additionally by several genetic studies. Up to date, more than 60 mutations of the $\mathrm{BChE}$ gene have been identified, including point mutations, small insertions and deletions (Parnas et al. 2001). Lower $\mathrm{BChE}$ activity originating from gene mutations was shown to be associated in human subjects with increased TG plasma levels and higher risk of obesity (Chaves et al. 2013, Lima et al. 2013).

Despite the site at which BChE fits into the lipid metabolic pathways has not yet been identified, fluctuations of the $\mathrm{BChE}$ activity related to lipid metabolism might carry clinical consequences. BChE serves not only as one of the markers in the liver function test, but is also an important enzyme responsible for the biotransformation of many xenobiotics, including medicaments. Accordingly, the level of BChE activity influences potentially the overall pharmacokinetic profile of these medicaments (Pohanka 2013).

In prophylaxis and supportive treatment of liver disorders related to excessive TG accumulation often the natural lipotropic compound betaine is used in praxis (Purohit et al. 2007). Betaine is produced in vivo via the oxidation of choline, but it is also present in many foods, such as spinach, sugar beet or whole wheat breads and grains. Betaine serves as a methyl donor and affects in this way the methionine-homocysteine equilibrium in favour of methionine, leading to increased formation of S-adenosylmethionine, one of the most important methyl transferring agents in cells (Kathirvel et al. 2010). On the other hand, long-term consumption of high-fat diet evokes methyl donor deficiency and hyperhomocysteinemia, a state which is linked to decreased secretion of TG-rich VLDL (very low-density lipoproteins) into circulation and development of steatosis (Craig et al. 2004, Chang et al. 2010). Although the exact mechanism coupling the hypomethylation state with steatosis has not yet been elucidated, it is supposed that impaired activities of methylation-dependent enzymes (Kharbanda et al.
2007) and methylation-controlled genes playing a role in the TG metabolism are involved (Wang et al. 2013). An example could be the rectification of the paradoxical PPAR $\alpha$ (peroxisome proliferator-activated receptor $\alpha$ ) gene promoter hypermethylation, caused by the overall hypomethylation state in the cell. PPAR $\alpha$ oversees the expression of several genes taking part in the TG breakdown and its expression is typically supressed in steatosis (Kohjima et al. 2007). It was shown, that betaine administration to mice suffering from steatosis led to decrease of the PPAR $\alpha$ gene promoter hypermethylation and subsequently increased expression in the liver (Wang et al. 2013).

From the above mentioned, it is clear that betaine interferes with the TG metabolism and its intake leads to steatosis elimination, which was proven by several animal (Kharbanda et al. 2007, 2011, Wang et al. 2010) and human (Miglio et al. 2000, Abdelmalek et al. 2001) studies. As BChE activity is hypothesized to be coupled to TG metabolism, the goal of this study was to evaluate the clinical implications of betaine treatment on $\mathrm{BChE}$ activity in plasma and liver of rats under the conditions of high-fat diet.

\section{Methods}

Animals, diets, chemicals and biochemicals

Animals and diets were from The Institute of Experimental Pharmacology and Toxicology, Slovak Academy of Sciences, Dobrá Voda, Slovak Republic. Reagents and chemicals used in all experiments were purchased from Sigma Aldrich (Slovak Republic), unless specified otherwise.

\section{Experimental design}

40 male Wistar rats weighing 215-295 g were used in the experiment. After 7-day adapting period, the animals were randomly divided into four groups by 10 and each group was fed for the following 4 weeks a different type of diet. The control group (C) was fed the standard diet. The high-fat diet group (HF) was fed the same diet with addition of pork lard $(16 \%$, w/w). The standard chow of the betaine group (B) was enriched with betaine $(2 \%, w / w)$. The HFB group was fed the standard diet containing both pork lard $(16 \%, \mathrm{w} / \mathrm{w})$ and betaine $(2 \%, w / w)$. Each day an equal chow portion was allocated to each animal cage in order to minimize the differences in the amounts of consumed chow.

Rats were sacrificed in pentobarbital anesthesia 
(i.p. $60 \mathrm{mg} / \mathrm{kg}, 2.5 \%$ solution) after overnight starvation. Whole blood was collected from the stomach vein into heparinized syringes and plasma was prepared by centrifugation after applying the blood samples on FicollPaque (15000 rpm at $\left.4{ }^{\circ} \mathrm{C}, 20 \mathrm{~min}\right)$. Livers were partially perfused with saline and immediately frozen in liquid nitrogen. Tissues were stored at $-80{ }^{\circ} \mathrm{C}$ until sample analysis.

In the course of the experiment the animals were supplied with water ad libitum. The care, use and procedures performed on these rats were approved by The State veterinary and food administration of the Slovak Republic (Ro-4295/12-221, from 20th December 2012).

\section{Preparation of tissue homogenates}

$20 \%$ liver homogenates were prepared in potassium phosphate buffer $(0.1 \mathrm{mmol} / 1, \mathrm{pH} 7.4)$ with $0.5 \%$ Triton X-100 and centrifuged at $15000 \mathrm{rpm}, 4{ }^{\circ} \mathrm{C}$, for $20 \mathrm{~min}$. Protein content in the samples was determined according to Bradford protocol (Bradford 1976).

\section{Biochemical laboratory analysis}

Determination of standard biochemical parameters in plasma - glucose, triglycerides, cholesterol, uric acid, alanine aminotransferase (ALT), aspartate aminotransferase (AST) and C-reactive protein (CRP) was carried out using the appropriate kits from Beckman Coulter on AU 400 analyzer (Beckman Coulter). All measurements were performed and evaluated by following the manufacturer's instructions. Thiobarbituric acid reactive substances (TBARS) were determined after extraction with $n$-butanol by spectrofluorimetric method (excitation wavelength $528 \mathrm{~nm}$, emission wavelength $558 \mathrm{~nm}$, spectrofluorometer Cary Eclipse, Varian) (Solichová et al. 2003).

For determination of GSH/GSSG ratio, ragent kit BIOXYTECH® GSH/GSSG-412 ${ }^{\mathrm{TM}}$ (OxisResearch, a division of OXIS Health Products, Inc.) was used; absorbance was read on spectrophotometer ECOM 6122 (Eppendorf).

Spectrophotometric estimation of butyrylcholinesterase activity

BChE activity was determined spectrophotometrically by the Ellman method (Ellman et al. 1961) in a total volume of $0.2 \mathrm{ml}$ on 96 -well plates. Samples were preincubated for $30 \mathrm{~min}$ with the specific acetylcholinesterase inhibitor (bw284c51; $0.02 \mathrm{mmol} / \mathrm{l}$ ) and 5,5-dithiobis(2-nitrobenzoic) acid $(0.625 \mathrm{mmol} / \mathrm{l})$ at $25^{\circ} \mathrm{C}$ in dark. The reaction was started by addition of the substrate - butyrylthiocholine iodide in the final concentration $0.625 \mathrm{mmol} / \mathrm{l}$. BChE enzyme activity was expressed in $\Delta$ O.D. per miligram of protein in the sample per minute.

\section{Total RNA isolation and cDNA synthesis}

The total RNA was isolated from $100 \mathrm{mg}$ of liver tissue using RNAzol-RT (Molecular Research Center, Inc., USA) following the instructions of the manufacturer. $500 \mathrm{ng}$ of total RNA was reversely transcribed using the PrimeScriptTM RT reagent kit (Takara Bio Inc., Japan).

\section{Real-time polymerase chain reaction}

Real-time PCR was performed with 5xHot FIREPol EvaGreen qPCR Mix Plus ROX kit (Solis Biodyne, Estonia). To determine the PPAR $\alpha$ gene expression specific primers were used (forward $5^{\prime} \rightarrow 3^{\prime}$ : AAGGGCTTCTTTCGGCGAAC; reverse $5^{\prime} \rightarrow 3^{\prime}$ : TGACCTTGTTCATGTTGAAGTTCTTCA; 21) (Qu et al. 2007) to give a $304 \mathrm{bp}$ product. The reaction was performed in a total volume of $20 \mu \mathrm{l}$ containing $100 \mathrm{ng}$ of sample cDNA $(2 \mu \mathrm{l}), 4 \mathrm{pmol}$ of each primer $(0.4 \mu \mathrm{l}), 4 \mu \mathrm{l}$ of EvaGreen with ROX and nuclease-free water to a final volume of $20 \mu \mathrm{l}$. Amplification and detection were done with a detection system Applied Biosystems ABI Prism 7300 Real Time PCR System with the profile of $95^{\circ} \mathrm{C}$ for $15 \mathrm{~min}$ followed with 40 cycles of $95^{\circ} \mathrm{C}$ for $30 \mathrm{~s}$, $60{ }^{\circ} \mathrm{C}$ for $30 \mathrm{~s}$ and $72{ }^{\circ} \mathrm{C}$ for $30 \mathrm{~s}$. The reaction was finished with the dissociation step. Transcription efficiency was analyzed with help of $\Delta \Delta \mathrm{Ct}$ value method (Winer et al. 1999), whereas the target gene $\mathrm{Ct}$ value was normalised by $\beta$-actin expression (forward $5^{\prime} \rightarrow 3^{\prime}$ : CCGCGAGTACAACCTTCTTG, reverse $5^{\prime} \rightarrow 3^{\prime}$ : GCAGC GATATCGTCATCCA) (Mackovičová et al. 2011), $81 \mathrm{bp}$ PCR product in the sample was analyzed under the same reaction conditions. PCR products were also evaluated by gel electrophoresis and melting curve analysis to confirm the specific amplification. To confirm gene DNA decontamination, reactions with RNA and water instead of cDNA were performed.

\section{Statistics}

Data were analyzed by one-way analysis of variance (ANOVA) using OriginPro 7.5, SR0, v7.5714 (B714), OriginLab Corporation, USA, followed by the Tukey's multiple comparision. Results are expressed as mean \pm standard deviation. Statistical significance was 
assumed for $\mathrm{P}<0.05(*), \mathrm{P}<0.01(* *)$ and $\mathrm{P}<0.001$ (***).

\section{Results}

The results of plasma biochemistry are summarized in Table 1. Consumption of high-fat diet induced increased glucose levels in plasma $(6.96 \pm 1.41$ (HF) vs. $4.52 \pm 0.43$ (C) mmol/l; $\mathrm{p}=0.002$ ), suppressed by concomitant betaine supplementation (3.24 \pm 1.47 (HFB) vs. $6.96 \pm 1.41(\mathrm{HF}) \mathrm{mmol} / \mathrm{l} ; \mathrm{p}=0.0012)$, even if rats were fed control diet $(3.55 \pm 0.28$ (B) vs. $4.52 \pm 0.43$ (C) mmol/l; $\mathrm{p}=0.001)$. TG were not significantly elevated in the highfat diet group $(0.30 \pm 0.17(\mathrm{HF})$ vs. $0.27 \pm 0.08(\mathrm{C}) \mathrm{mmol} / \mathrm{l}$; $\mathrm{p}=0.70$ ), but betaine income decreased their levels approximately by half in case of both diets $(0.13 \pm 0.03$ (HFB) vs. $0.30 \pm 0.17$ (HF) $\mathrm{mmol} / \mathrm{l} ; \mathrm{p}=0.005$ and $0.15 \pm 0.03$ (B) vs. $0.27 \pm 0.08$ (C) mmol/l; p=0.003). Betaine had no impact on the total cholesterol (TC) in rats fed standard diet $(0.78 \pm 0.06$ (B) vs. $0.84 \pm 0.09$ (C) $\mathrm{mmol} / \mathrm{l} ; \mathrm{p}=0.19)$, but its consumption prevented the significant TC increase recorded in the HF group $(0.84 \pm 0.09$ (HFB) vs. $1.18 \pm 0.15$ (HF) mmol/l; $\mathrm{p}=0.015)$.

Table 1. Animal weights and plasma biochemistry.

\begin{tabular}{|c|c|c|c|c|c|c|c|c|}
\hline & \multicolumn{2}{|c|}{$\mathbf{C}$} & \multicolumn{2}{|c|}{ HF } & \multicolumn{2}{|c|}{ B } & \multicolumn{2}{|c|}{ HFB } \\
\hline & mean & SD & mean & SD & mean & SD & mean & SD \\
\hline Weight gain (g) & 78.85 & 19.78 & $98.75^{*}$ & 6.94 & 76.00 & 18.84 & 98.89 & 6.52 \\
\hline GLC (mmol/l) & 4.52 & 0.43 & $6.96 * *$ & 1.41 & $3.55^{* * *}$ & 0.28 & 3.24 \#\# & 1.47 \\
\hline$T G(\mathrm{mmol} / \mathrm{l})$ & 0.27 & 0.08 & 0.30 & 0.17 & $0.15^{* *}$ & 0.03 & $0.13 * *$ & 0.03 \\
\hline$T C(\mathrm{mmol} / \mathrm{l})$ & 0.84 & 0.09 & $1.18^{* *}$ & 0.15 & 0.78 & 0.06 & $0.84^{\#}$ & 0.24 \\
\hline$A L T(\mu k a t / l)$ & 0.28 & 0.03 & $0.44 * * *$ & 0.10 & 0.31 & 0.06 & $0.39 * *$ & 0.07 \\
\hline AST ( $\mu \mathrm{kat} / \mathrm{l})$ & 1.60 & 0.30 & 1.53 & 0.26 & $1.24 *$ & 0.26 & $0.91 * * * *$ & 0.41 \\
\hline$C R P(m g / l)$ & 167.50 & 26.46 & $248.50 * *$ & 60.36 & 176.90 & 28.34 & 205.40 & 39.45 \\
\hline TBARS ( & 0.34 & 0.04 & $0.49 * *$ & 0.11 & $0.51 * * *$ & 0.04 & $0.48^{*}$ & 0.11 \\
\hline$U A(\mu m o l / l)$ & 61.67 & 8.82 & 51.13 & 10.16 & $41.38 * * *$ & 5.07 & $34.50 * * * / \# \#$ & 6.29 \\
\hline$G S H / G S S G$ & 6.92 & 1.41 & $5.14^{*}$ & 0.47 & $8.91 *$ & 1.35 & $7.82^{\# \# \#}$ & 0.51 \\
\hline
\end{tabular}

GLC - glucose, TG - triglycerides, TC - total cholesterol, ALT - alanine aminotransferase, ALT - aspartate aminotransferase, CRP - C-reactive protein, TBARS - thiobarbituric acid reactive substances, UA - uric acid, GSH - glutathione, GSSG - oxidized glutathione. Results are given as mean \pm SD. Symbol * indicates statistic different value from $C$ at $P<0.05(*), P<0.001(* *)$ and $\mathrm{P}<0.001(* * *)$. Symbol ${ }^{\#}$ indicates statistic different value from HF at $\mathrm{P}<0.05\left({ }^{\#}\right), \mathrm{P}<0.001\left({ }^{\#}\right)$ and $\mathrm{P}<0.001\left({ }^{\# \#}\right)$.

Betaine intake affected also one of the two general markers of hepatocellular injury - AST. Whereas the concentrations of AST remained unchanged in the HF group (1.53 \pm 0.26 (HF) vs. $1.60 \pm 0.30$ (C); mmol/l; $\mathrm{p}=0.64$ ), betaine caused a significant drop of this parameter regardless the type of diet betaine was added to (1.24 \pm 0.26 (B) vs. $1.60 \pm 0.30(\mathrm{C}) ; \mathrm{mmol} / \mathrm{l} ; \mathrm{p}=0.031$ and $0.91 \pm 0.41$ (HFB) vs. $1.53 \pm 0.26(\mathrm{HF}) ; \mathrm{mmol} / \mathrm{l} ; \mathrm{p}=0.005)$. By contrast, betaine had no impact on ALT, which was significantly increased in plasma of animals on high-fat $\operatorname{diet}(0.44 \pm 0.10$ (HF) vs. $0.28 \pm 0.03$ (C) mmol/l; $\mathrm{p}<0.001)$.

$\mathrm{HF}$ diet consumption resulted in increased CRP levels, signaling pro-inflammatory state. Despite we observed lower CRP in the HFB group, this decrease was not significant due to the high SD values in both groups. Compared to control, increased levels of TBARS representing lipid associated oxidative stress were observed in all groups, the most significant increase was caused by betaine consumption with the standard diet $(0.51 \pm 0.04$ (B) vs. $0.34 \pm 0.04$ (C) $\mathrm{mg} / \mathrm{l} ; \mathrm{p}<0.001)$. Although statistically uric acid (UA) levels in the HF group equaled to those in the $\mathrm{C}$ group, betaine intervention was clear in terms of decreased levels, when used in both groups $(41.38 \pm 5.07$ (B) vs. $64.00 \pm 10.15$ (C) $\mu \mathrm{mol} / \mathrm{l} ; \mathrm{p}<0.001$ and $34.50 \pm 6.29$ (HFB) vs. $52.29 \pm 10.39$ (HF) $\mu \mathrm{mol} / \mathrm{l} ; \mathrm{p}=0.004$ ). Another marker of oxidative stress, the GSH/GSSG ratio was slightly decreased in the HF group (5.14 \pm 0.47 (HF) vs. $6.92 \pm 1.41$ (C); $\mathrm{p}=0.01)$ and recovered to control value along with betaine treatment $\quad(7.82 \pm 0.51 \quad$ (HFB) vs. $5.14 \pm 0.47 \quad$ (HF); $\mathrm{p}<0.001)$. Betaine raised the GSH/GSSG ratio even in the group of animals on standard diet $(8.91 \pm 1.35$ (B) vs. $6.92 \pm 1.41(\mathrm{C}) ; \mathrm{p}=0.04)$. 


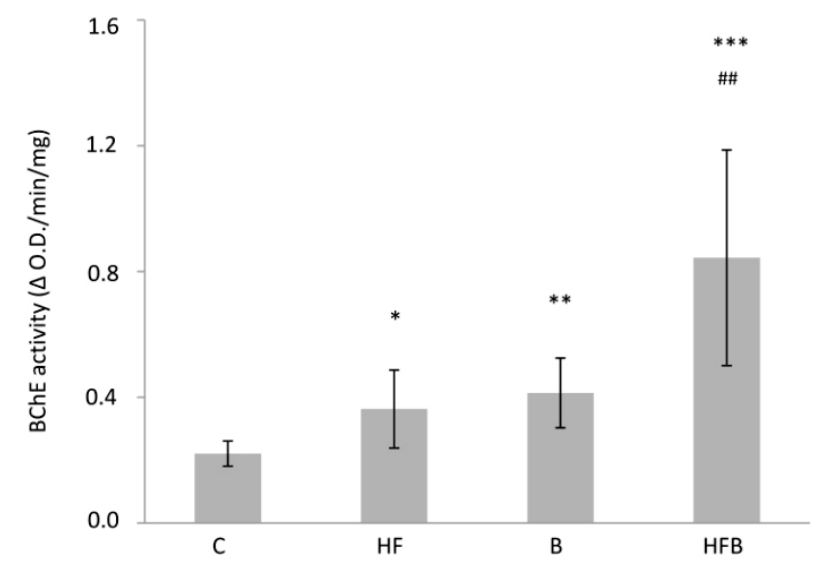

Fig. 1. Butyrylcholinesterase activity in plasma of Wistar rats after 4 weeks on different diets. BChE activity was estimated on substrate butyrylthiocholine iodide, the results are given as mean values $\pm \mathrm{SD}$. C - control, HF - high-fat diet, B - betaine, HFB high-fat diet + betaine; $*$ is statistically different from $C_{\text {, }}^{\#}$ is statistically different from HF. Symbol $*$ indicates statistic different value from $\mathrm{C}$ at $\mathrm{P}<0.05(*), \mathrm{P}<0.001\left(^{* *}\right)$ and $\mathrm{P}<0.001$ $(* * *)$. Symbol ${ }^{*}$ indicates statistic different value from HF at $\mathrm{P}<0.05\left({ }^{\#}\right), \mathrm{P}<0.001\left(^{\# \#}\right)$ and $\mathrm{P}<0.001\left(^{\# \# \#)}\right.$.

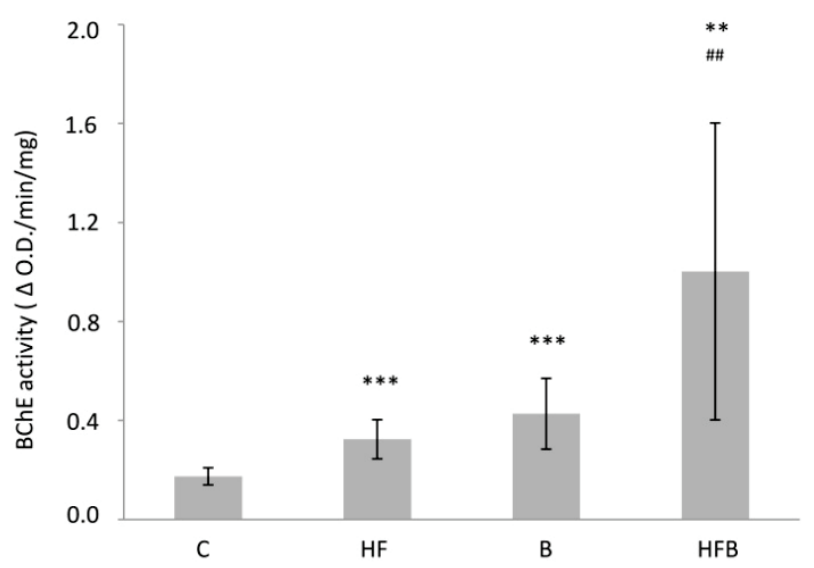

Fig. 2. Butyrylcholinesterase activity in the liver homogenates of Wistar rats after 4 weeks on different diets. BChE activity was estimated on substrate butyrylthiocholine iodide, the results are given as mean values \pm SD. C - control, HF - high-fat diet, $\mathrm{B}$ - betaine, HFB - high-fat diet + betaine; * is statistically different from $\mathrm{C}_{1}{ }^{\#}$ is statistically different from HF. Symbol * indicates statistic different value from $\mathrm{C}$ at $\mathrm{P}<0.05\left(^{*}\right), \mathrm{P}<0.001$ $(* *)$ and $\mathrm{P}<0.001(* * *)$. Symbol ${ }^{\#}$ indicates statistic different value from HF at $\mathrm{P}<0.05\left({ }^{\#}\right), \mathrm{P}<0.001\left({ }^{\# \#}\right)$ and $\mathrm{P}<0.001\left({ }^{\# \# \#)}\right.$.

The butyrylcholinesterase activity was measured in rat plasma and liver homogenates. In plasma, both high-fat diet and betaine intake led to significantly elevated BChE activity $(0.36 \pm 0.12$ (HF) vs. $0.22 \pm 0.04$ (C) O.D. $/ \mathrm{min} / \mathrm{mg} ; \mathrm{p}=0.014$ and $0.41 \pm 0.12$ (B) vs. $0.22 \pm 0.04$ (C) O.D. $/ \mathrm{min} / \mathrm{mg} ; \mathrm{p}=0.0012$ ), which was even potentiated, when betaine was combined with high-fat diet $(0.84 \pm 0.34$ (HFB) vs. $0.22 \pm 0.04$ (C) O.D. $/ \mathrm{min} / \mathrm{mg}$; $\mathrm{p}<0.001$, Fig. 1). The same pattern of BChE activity was

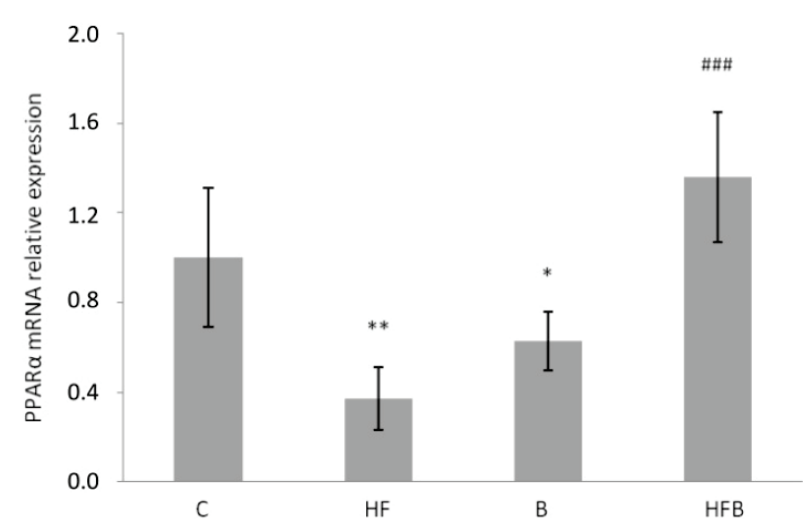

Fig. 3. PPARa gene expression in the liver of Wistar rats after 4 weeks on different diets. Relative changes of PPARa gene expression are given as PPARa mRNA normalized to $\beta$-actine mRNA, whereas control was preset at 1 . The results are given as mean values $\pm \mathrm{SD}$. $\mathrm{C}$ - control, $\mathrm{HF}$ - high-fat diet, $\mathrm{B}$ - betaine, HFB - high-fat diet + betaine; * is statistically different from C, \# is statistically different from HF. Symbol * indicates statistic different value from $\mathrm{C}$ at $\mathrm{P}<0.05\left(^{*}\right), \mathrm{P}<0.001(* *)$ and $\mathrm{P}<0.001$ $(* * *)$. Symbol \# indicates statistic different value from HF at

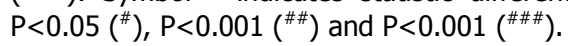

observed in the liver (Fig. 2), with even more significant $\mathrm{BChE}$ activity rise in $\mathrm{HF}$ and $\mathrm{B}$ group, compared to control. But similarly to plasma, the combination of highfat diet and betaine eventuated in more than fivefold of the BChE activity in the control group $(1.00 \pm 0.60$ (HFB) vs. $0.17 \pm 0.03$ (C) O.D. $/ \mathrm{min} / \mathrm{mg} ; \mathrm{p}=0.0011$ ).

The PPAR $\alpha$ gene expression in the liver turned out to be suppressed as a result of high-fat diet as well as betaine intake. Surprisingly the same effect was not recorded in the HFB group with parallel high-fat diet and betaine consumption, where the PPAR $\alpha$ mRNA levels did not differ substantially from those in the control group (Fig. 3).

\section{Discussion}

The enzyme butyrylcholinesterase is expressed in several tissues (brain, lungs, liver, gut, adipose tissue, heart and others), but the BChE activity in plasma reflects primarily the level of its synthesis in the liver. The knowledge that $\mathrm{BChE}$ is secreted into plasma from liver at a constant rate is relevant mainly to the clinical practice, where estimation of the enzyme's activity serves as one of the markers in the liver function test. Altered BChE activity is generally considered to be the consequence of severe chronic liver disorders. While decreased $\mathrm{BChE}$ activity is ascribed to distinct liver damages profoundly reducing its function, such as steatosis, fibrosis, cirrhosis or hepatitis, increased $\mathrm{BChE}$ 
activity occurs rather rarely as the outcome of hepatocellular carcinoma (Pohanka 2013). There are only a few other pathological conditions influencing the BChE activity, including renal diseases, burns or intoxications (Soliday et al. 2010).

In the last two decades BChE activity changes have been often discussed as the consequence of its possible integration in the lipid metabolic pathways, particularly TG turnover, whereby a certain mechanism has not been elucidated so far. Positive correlations between BChE activity and TG levels in plasma were proven repeatedly in subjects suffering from obesity, diabetes or metabolic syndrome (Rustemeijer et al. 2001, Alcantara et al. 2002, Iwasaki et al. 2007), whereas inhibition of BChE activity was found to be accompanied by decreased TG plasma levels (Annapurna et al. 1991, Iwasaki et al. 2007). We hypothesized, that the natural compound betaine, used for the treatment of liver disorders (Purohit et al. 2007), which was also shown to lead to TG decrease in plasma (Hayesa et al. 2003, Kawakami et al. 2012) might evoke modifications of BChE activity. Betaine did not alter the animal's weight gain after one month, no matter whether on standard, or high-fat diet. However its intake was beneficial for normalizing the levels of GLC, AST and CRP and it even increased the ratio GSH/GSSG pointing to decreased oxidation stress burden (Table 1). The levels of plasma GLC dropped in both groups treated with betaine (B and HFB) below the control levels. The effect of betaine on GLC metabolism was studied by Kathirvel et al. (2010), who reported GLC decrease in mice on high-fat diet after a long-term betaine intake along with improved hepatic insulin resistance. Inhibition of gluconeogenesis and increased use of glucose in glycogen synthesis were proven to contribute to this effect of betaine, although participation of other mechanisms was not excluded.

As expected, we recorded major changes in BChE plasma activity following betaine treatment, but while betaine led to the expected decrease of plasma TG (Table 1), BChE activity in plasma was elevated (Fig. 1). Compared to control, betaine treatment led to approximately equal TG decrease in B and HFB groups
(Table 1), but the BChE activity was significantly higher in the HFB group compared to the B group (Fig. 1). In contrast, despite there was no statistically significant rise of plasma $\mathrm{TG}$ in the $\mathrm{HF}$ group due to the extreme variance of this parameter (Table 1), the BChE activity in plasma increased (Fig. 1). To sum up the observed BChE activity fluctuations, based on our results we could not draw a general rule stating positive nor negative correlations between BChE activity and TG levels in plasma. The PPAR $\alpha$ gene expression was decreased in animals on high-fat diet and this effect could be reversed by betaine intake in the HFB group (Fig. 3). The same result was attained in mice with steatosis after betaine administration (Wang et al. 2013). In our previous rat experiment we used the hypolipidemic drug fenofibrate, which acts as PPAR $\alpha$ ligand to decrease the plasma TG in order to determine whether the plasma $\mathrm{BChE}$ activity will decrease. Similar to betaine treatment, the decrease of plasma TG was accompanied by enhanced BChE activity, again observing a more prominent rise in the group consuming high-fat diet (Šišková et al. 2012). Increased expression of $\operatorname{PPAR} \alpha$ along with elevated BChE activity support the hypothesis of $\mathrm{BChE}$ playing a role in the fat utilization process (Li et al. 2008).

In conclusion, even though the mechanism is unknown, the BChE activity in plasma is significantly elevated during betaine intake and this should be taken into account when $\mathrm{BChE}$ activity is interpreted as a marker in the liver function test.

\section{Conflict of Interest}

There is no conflict of interest.

\section{Acknowledgements}

This publication is the result of the project implementation: „Support of establishment, development, and mobility of quality research teams at the Charles University“, registration number CZ.1.07/2.3.00/30.0022, supported by The Education for Competitiveness Operational Programme (ECOP) funded by the European Social Fund (ESF) and the government budget of the Czech Republic.

\section{References}

ABDELMALEK MF, ANGULO P, JORGENSEN RA, SYLVESTRE PB, LINDOR KD: Betaine, a promising new agent for patients with nonalcoholic steatohepatitis: results of a pilot study. Am J Gastroenterol 96: 2711-2717, 2001. 
ALCANTARA VM, CHAUTARD-FREIRE-MAIA EA, SCARTEZINI M, CERCI MSJ, BRAUN-PRADO K, PICHETH G: Butyrylcholinesterase activity and risk factors for coronary artery disease. Scand J Clin Lab Invest 62: 399-404, 2002.

ANNAPURNA V, SENCIALL I, DAVIS AJ, KUTTY KM: Relationship between serum pseudocholinesterase and triglycerides in experimentally induced diabetes mellitus in rats. Diabetologia 34: 320-324, 1991.

BRADFORD MM: Rapid and sensitive method for the quantitation of microgram quantities of protein utilizing the principle of protein-dye binding. Anal Biochem 72: 248-254, 1976.

CHANG X, YAN H, FEI J, JIANG M, ZHU H, LU D, GAO X: Berberine reduces methylation of the MTTP promoter and alleviates fatty liver induced by a high-fat diet in rats. J Lipid Res 51: 2504-2515, 2010.

CHAVES TJ, LEITE N, MILANO GE, MILANO GE, SOUZA RLR, CHAUTARD-FREIRE-MAIA EA, FURTADOALLE L: -116A and K BCHE gene variants associated with obesity and hypertriglyceridemia in adolescents from Southern Brazil. Chem Biol Interac 203: 341-343, 2013.

COKUGRAS AN: Butyrylcholinesterase: structure and physiological importance. Turk J Biochem 28: 54-61, 2003.

CRAIG SA: Betaine in human nutrition. Am J Clin Nutr 80: 539-549, 2004.

ELLMAN GL, COURTNEY KD, ANDRES V JR, FEATHER-STONE RM: Anew and rapid colorimetric determination of acetylcholinesterase activity. Biochem Pharmacol 7: 88-95, 1961.

HAYESA KC, PRONCZUKA A, COOKB MW, ROBBINS MC: Betaine in sub-acute and sub-chronic rat studies. Food Chem Toxicol 41: 1685-1700, 2003.

IWASAKI T, YONEDA M, NAKAJIMA A, TERAUCHI Y: Serum butyrylcholinesterase is strongly associated with adiposity, the serum lipid profile and insulin resistance. Intern Med 46: 1633-1639, 2007.

KATHIRVEL E, MORGAN K, NANDGIRI G, SANDOVAL BC, CAUDILL MA, BOTTIGLIERI T, FRENCH SW, MORGAN TR: Betaine improves nonalcoholic fatty liver and associated hepatic insulin resistance: a potential mechanism for hepatoprotection by betaine. Am J Physiol Gastrointest Liver Physiol 299: G1068-G1077, 2010.

KAWAKAMI S, HAN KH, NAKAMURA Y, SHIMADA K, KITANO T, ARITSUKA T, NAGURA T, OHBA K, NAKAMURA K, FUKUSHIMA M: Effects of dietary supplementation with betaine on nonalcoholic steatohepatitis (NASH) mouse model. J Nutr Sci Vitaminol (Tokyo) 58: 371-375, 2012.

KHARBANDA KK, MAILLIARD ME, BALDWIN CR, BECKENHAUER HC, SORRELL MF, TUMA DJ: Betaine attenuates alcoholic steatosis by restoring phosphatidylcholine generation via the phosphatidylethanolamine methyltransferase pathway. J Hepatol 46: 314-321, 2007.

KHARBANDA KK, TODERO SL, KING AL, OSNA NA, MCVICKER BL, TUMA DJ, WISECARVER JL, BAILEY SM: Betaine treatment attenuates chronic ethanol-induced hepatic steatosis and alterations to themitochondrial respiratory chain proteome. Internat J Hepatol 2012: 962183, 2011.

KOHJIMA M, ENJOJI M, HIGUCHI N, KATO M, KOTOH K, YOSHIMOTO T, FUJINO T, YADA M, YADA R, HARADA N, TAKAYANAGI R, NAKAMUTA M: Re-evaluation of fatty acid metabolism related gene expression in nonalcoholic fatty liver disease. Int J Mol Med 20: 351-358, 2007.

LI B, DUYSEN EG, LOCKRIDGE O: The butyrylcholinesterase knockout mouse is obese on a high-fat diet. Chem Biol Interact 175: 88-91, 2008.

LIMA JK, LEITE N, TUREK LV, SOUZA RLR, DA SILVA TIMOSSI L, OSIECKI ACV, OSIECKI R, FURTADOALLE L: 1914G variant of BCHE gene associated with enzyme activity, obesity and triglyceride levels. Gene 532: 24-26, 2013.

MACKOVIČOVÁ K, GAŽOVÁ A, KUČEROVÁ D, GAJDÁČOVÁ B, KLIMAS J, OCHODNICKÝ P, GONCALVESOVÁ E, KYSELOVIČ J, KŘENEK P: Enalapril decreases cardiac mass and fetal gene expression without affecting the expression of endothelin-1, transforming growth factor b-1, or cardiotrophin-1 in the healthy normotensive rat. Can J Physiol Pharmacol 89: 197-205, 2011.

MIGLIO F, ROVATI LC, SANTORO A, SETNIKAR I: Efficacy and safety of oral betaine glucuronate in nonalcoholic steatohepatitis. A double-blind, randomized, parallel-group, placebo-controlled prospective clinical study. Arzneimittelforschung 50: 722-727, 2000.

PARNAS ML, PROCTER M, SCHWARZ MA, MAO R, GRENACHE DG: Concordance of butyrylcholinesterase phenotype with genotype implications for biochemical reporting. Am J Clin Path 135: 271-276, 2001. 
POHANKA M: Butyrylcholinesterase as a biochemical marker. Bratisl Lek Listy 114: 726-734, 2013.

PUROHIT V, ABDELMALEK MF, BARVE S, BENEVENGA NJ, HALSTED CH, KAPLOWITZ N, KHARBANDA KK, LIU Q, LU SC, MCCLAIN CJ, SWANSON C, ZAKHARI S: Role of S-adenosylmethionine, folate, and betaine in the treatment of alcoholic liver disease: summary of a symposium. Am J Clin Nutr 86: 14-24, 2007.

QU S, SU D, ALTOMONTE J, KAMAGATE A, HE J, PERDOMO G, TSE T, JIANG Y, DONG HH: PPAR mediates the hypolipidemic action of fibrates by antagonizing FoxO1. Am J Physiol Endocrinol Metab 292: 421-434, 2007.

RUSTEMEIJER C, SCHOUTEN JA, VOERMAN HJ, BEYNEN AC, DONKER AJM, HEINE RJ: Is pseudocholinesterase activity related to markers of triacylglycerol synthesis in type II diabetes mellitus? Clin Sci 101: 29-35, 2001.

SOLICHOVÁ D, MELICHAR B, KLEJNA M, JURAŠKOVÁ B, KRÁLOVSKÁ L, BLÁHA V, ZĎÁNSKÝ P, ZADÁK Z: Fluorimetric determination of the levels of urinary neopterin and serum thiobarbituric acid reactive substances in the nonagenarians. Talanta 60: 459-465, 2003.

SOLIDAY FK, CONLEY YP, HENKER R: Pseudocholinesterase deficiency: a comprehensive review of genetic, acquired, and drug influences. AANA Journal 78: 313-320, 2010.

ŠIŠKOVÁ K, BILKA F, ADAMEOVÁ A, BALÁŽOVÁ A, MYDLA M, PAULIKOVÁ I: Influence of lipid imbalance on butyrylcholinesterase activity and biotransformation efficiency. Pharmazie 67: 345-350, 2012.

WANG Z, YAO T, PINI M, ZHOU Z, FANTUZZI G, SONG Z: Betaine improved adipose tissue function in mice fed a high-fat diet: a mechanism for hepatoprotective effect of betaine in nonalcoholic fatty liver disease. $A m J$ Physiol Gastrointest Liver Physiol 298: G634-G642, 2010.

WANG L, CHEN L, TAN Y, WEI J, CHANG Y, JIN T, ZHU H: Betaine supplement alleviates hepatic triglyceride accumulation of apolipoprotein $\mathrm{E}$ deficient mice via reducing methylation of peroxisomal proliferator-activated receptor alpha promoter. Lipids Health Dis 12: 34, 2013.

WINER J, JUNG CK, SHACKEL I, WILLIAMS PM: Development and validation of real-time quantitative reverse ranscriptasepolymerase chain reaction for monitoring gene expression in cardiac myocytes in vitro. Anal Biochem 270: 41-49, 1999. 